Original Article

\title{
Identification of locally isolated entomopathogenic Fusarium species from the soil of Changa Manga Forest, Pakistan and evaluation of their larvicidal efficacy against Aedes aegypti
}

\author{
Identificação de espécies de Fusarium entomopatogênicas localmente isoladas do solo \\ da Floresta de Changa Manga, Paquistão e avaliação de sua eficácia larvicida contra \\ Aedes aegypti
}

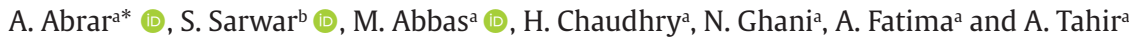 \\ aLahore College for Women University, Environmental Science Department, Lahore, Pakistan \\ bLahore College for Women University, Botany Department, Lahore, Pakistan
}

\begin{abstract}
Dengue fever vectored by the mosquito Aedes aegypti is one of the most rapidly spreading insect-borne diseases. Current reliance of dengue vector control is mostly on chemical insecticides. Growing insecticide resistance in the primary mosquito vector, Aedes aegypti, limits the effectiveness of vector control through chemical insecticides. These chemical insecticides also have negative environmental impacts on animals, plants and human health. Myco-biocontrol agents are naturally occurring organisms and are found to be less damaging to the environment as compared to chemical insecticides. In the present study, entomopathogenic potential of local strains of fungi isolated from soil was assessed for the control of dengue vector. Local fungal isolates presents better alternative to introducing a foreign biocontrol strain, as they may be better adapted to environmental conditions of the area to survive and may have more entomopathogenic efficacy against target organism. Larvicidal efficacy of Fusarium equiseti and Fusarium proliferatum was evaluated against Aedes aegypti. Local strains of $F$. equiseti (MK371718) and F. proliferatum (MK371715) were isolated from the soil of Changa Manga Forest, Pakistan by using insect bait method. Larvicidal activity of two Fusarium spp. was tested against forth instar larvae of A. aegypti in the laboratory, using concentrations $10^{5}, 10^{6}$, $10^{7}$ and $10^{8}$ conidia $/ \mathrm{ml} \mathrm{LC}_{50}$ values for $F$. equiseti after $24 \mathrm{~h}, 48 \mathrm{~h}, 72 \mathrm{~h}$ and $96 \mathrm{~h}$ of exposure were recorded as $3.8 \mathrm{x}$ $10^{8}, 2.9 \times 10^{7}, 2.0 \times 10^{7}$, and $7.1 \times 10^{6}$ conidia $/ \mathrm{ml}$ respectively while $\mathrm{LC}_{50}$ values for $F$. proliferatum were recorded as $1.21 \times 10^{8}, 9.6 \times 10^{7}, 4.2 \times 10^{7}, 2.6 \times 10^{7}$ conidia $/ \mathrm{ml}$ respectively after $24 \mathrm{~h}, 48 \mathrm{~h}, 72 \mathrm{~h}$ and $96 \mathrm{~h}$ of exposure. The results indicate that among two fungal strains $F$. equiseti was found to be more effective in terms of its larvicidal activity than $F$. proliferatum against larvae of $A$. aegypti.
\end{abstract}

Keywords: fungi, vector control, entomopathogenic, larvicidal activity.

\begin{abstract}
Resumo
A dengue transmitida pelo mosquito Aedes aegypti é uma das doenças transmitidas por insetos de propagação mais rápida. A dependência atual do controle do vetor da dengue é principalmente de inseticidas químicos. $\mathrm{O}$ aumento da resistência a inseticidas no principal vetor do mosquito, Aedes aegypti, limita a eficácia do controle do vetor por meio de inseticidas químicos. Esses inseticidas químicos também têm impactos ambientais negativos sobre os animais, plantas e saúde humana. Os agentes de micobiocontrole são organismos que ocorrem naturalmente e são menos prejudiciais ao meio ambiente em comparação com os inseticidas químicos. No presente estudo, avaliouse o potencial entomopatogênico de cepas locais de fungos isolados do solo para o controle do vetor da dengue. Isolados de fungos locais apresentam melhor alternativa para a introdução de uma cepa de biocontrole estrangeira, pois podem ser mais bem adaptados às condições ambientais da área para sobreviver e podem ter maior eficácia entomopatogênica contra o organismo-alvo. A eficácia larvicida de Fusarium equiseti e Fusarium proliferatum foi avaliada contra Aedes aegypti. Cepas locais de F. equiseti (MK371718) e F. proliferatum (MK371715) foram isoladas do solo de Changa Manga Forest, Paquistão, usando o método de isca para insetos. Atividade larvicida de dois Fusarium spp. foi testado contra larvas de quarto ínstar de A. aegypti em laboratório, nas concentrações 105, 106, 107 e 108 conídios / ml. Os valores de LC50 para F. equiseti após 24 h, 48 h, 72 h e 96 h de exposição foram registrados como 3,8x 108, 2,9x107, 2,0x107 e 7,1×106 conídios / ml, respectivamente, enquanto os valores de LC50 para $F$. proliferatum foram registrados como 1,21×108, 9,6 x107, 4,2×107, 2,6×107 conídios / ml, respectivamente, após 24 h, 48 h, 72 h e 96 h de exposição. Os resultados indicam que entre duas cepas de fungos F. equiseti se mostrou mais eficaz em termos de atividade larvicida do que $F$. proliferatum contra larvas de A. aegypti.
\end{abstract}

Palavras-chave: fungos, controle de vetores, entomopatogênica, atividade larvicida.

*e-mail: amina.abrar@outlook.com

Received: December 4, 2020 - Accepted: April 2, 2021

This is an Open Access article distributed under the terms of the Creative Commons Attribution License, which permits unrestricted use, distribution, and reproduction in any medium, provided the original work is properly cited. 


\section{Introduction}

Dengue is one of the most prominent vector-borne diseases in Pakistan. Its incidence is emerging despite the implementation of routine national dengue control program. The potential vector and supporting environmental conditions which promote the infectious agent to proliferate are playing important role in spreading dengue. The etiological agent for dengue is arbovirus and the major vector responsible to transmit the disease is $A$. aegypti (Heinisch et al., 2019).

Application of chemical insecticides is the widely used control method for dengue vector, which heavily contaminate the environment and negatively affect humans and other organisms. Therefore scientists are searching for safer alternative methods of dengue vector control (Nassar, 2018). Biological control is a promising and potentially effective replacement to chemical insecticides. It employs the deliberate use of microorganisms for regulating the population of dengue vector and preventing the transmission of disease (Hajek and Eilenberg, 2018). Entomopathogenic fungi are among the wide spread group of microorganisms which are used to provide biocontrol against insects (Jaber and Ownley, 2018). Entomopathogenic fungi are natural foes of insects with cosmopolitan existence and rich diversity, presenting a sustainable solution for dengue vector control (Antonio et al., 2001, Araujo and Hughes, 2016). These fungi are pathogenic to insects and due to their eco-friendliness these are preferred to kill insects at various stages of insect life cycle (Shang et al., 2015).

Various strains of fungi present effective control against disease spreading insects. Laboratory bioassays provide basis for the control of disease causing insects in field. In many research studies, the entomopathogenic fungi are reported to be an effective biological control tool against various insect spp. (Feng et al., 1994; Shah and Pell, 2003; Charnley and Collins, 2007; Araujo and Hughes, 2016; Lovett et al., 2019). The current study lies in accordance with previous studies using entomopathogenic fungi for control of Aedes aegypti (Dong et al., 2012; Evans et al., 2018; Vasantha-Srinivasan et al., 2019). Fusarium is a large genus of filamentous fungi abundantly found in soil, associated with both living and dead animals. Among animals most of the Fusarium spp. are primarily found in association with insects. Some species of Fusarium are found to be strong entomopathogens of members of order dipteran and homopteran in laboratory bioassays and field observations. Most of these spp. show high host specificity and minimal damage to non target organisms (Teetor-Barsch and Roberts, 1983; Brimner and Boland, 2003; Dutta, 2015.). Fusarium equiseti and Fusarium proliferatum are reported to be entomopathogens of many insect species including Tribolium confusum, Galleria mellonella, Cephus cinctus, Brahmina coriacea etc. according to various research studies (Al-Ani et al., 2018, Kalaimurugan et al., 2019; Santos et al., 2020; Akhter et al., 2021). Entomopathogenic fungi are widely distributed in a wide range of terrestrial ecosystems including forest, agricultural and pasture habitats (Pell et al., 2001, Nidhi et al., 2018). Changa Manga forest is a man-made forest in Pakistan. The soil properties of this forest serve an ideal habitat for a vast variety of entomopathogenic fungi (Abrar et al., 2020). Objectives of the present research are to identify the local strains of Fusarium spp. isolated from soil of Changa Manga forest,
Pakistan and to evaluate the larvicidal efficacy of these isolates against larvae of Aedes aegypti.

\section{Methodology}

\subsection{Isolation of $F$. equiseti and $F$. prolifertum}

Local strains of Entomopathogenic $F$. equiseti and $F$ .proliferatum were isolated from Changa Manga Forest, Pakistan. Changa Manga ( $31^{\circ} 05^{\circ} 01.9^{\prime \prime} \mathrm{N}$ and $73^{\circ} 59^{\circ} 45.1^{\prime \prime E}$ ) is a forested area located $60 \mathrm{~km}$ away from Lahore within the District of Kasur. The total area is 12510 hectors approximately. The soil of the Changa Manga Forest is highly porous, dark brown in color with silty loam texture. The soil of the forest is considered to be healthy and fertile for the plantation of trees and supports a variety of soil born fungi. The $\mathrm{pH}$ of soil ranges from 7.7 to 8.0. Isolation of fungi from soil samples collected from Changa Manga Forest was attempted using the Galleria bait method (Meyling and Eilenberg, 2006). Final instars of wax moth (Galleria mellonella) were used as bait insects. Wax moth larvae were surface-sterilized using $1 \%$ sodium hypochlorite and rinsing them in distilled water, and incubated at $25^{\circ} \mathrm{C} .1 \mathrm{~g}$ of Soil sample sprinkled on PDA petri plates with 10 larvae of wax moth in each soil sample was used for baiting. Samples were observed after 7 days to check any fungal growth for the first time and on daily basis after initial seven days. Colonies of Fusarium species found in soil samples were isolated and subcultures on PDA plates to obtain the fungal strain on separate plate. The pure cultures of fungal isolates were mass cultured PDA plates.

\subsection{Identification and phylogenetic analysis of fungal isolates}

Isolated Fusarium spp. were identified on basis of morphological traits using taxonomic key (Summerell et al., 2003; Nayyar et al., 2018) and with the help of experts. For DNA extraction fungal mycelia was obtained after $10 \mathrm{~min}$ of centrifugation at $17500 \mathrm{rpm}$ and $300 \mu \mathrm{l}$ of extraction buffer (200mM Tris-HCl, pH 8.5, 250mM NaCl, 25mM EDTA, $0.5 \%$ SDS) was added in culture media. The suspension was vortexed with $2.8 \mathrm{~mm}$ stainless steel beads during 10 minutes. After centrifugation at $17500 \mathrm{rpm}$ for $10 \mathrm{~min}$, $150 \mu \mathrm{l}$ of $3 \mathrm{M}$ sodium acetate ( $\mathrm{pH}$ 5.2) was added to the supernatant. The supernatant was incubated at $-20^{\circ} \mathrm{C}$ for 10 more minutes and centrifuged ( $17500 \mathrm{rpm}, 10 \mathrm{~min}$ ). The DNA-containing supernatant was transferred to a new tube and nucleic acids were precipitated by adding 1 volume of isopropyl alcohol. After 5 minutes of incubation at room temperature the DNA suspension was centrifuged (17500 rpm, $10 \mathrm{~min}$ ). The (DNA) pellets were washed with $70 \%$ ethanol to remove residual salts. Finally, the pellets were air-dried and the DNA was re-suspended in $50 \mu$ of buffer (10mM Tris-HCl (pH 8), 1mM EDTA).

Specific PCR assays were carried out using primers NS1 5' (GTA GTC ATA TGC TTG TCT C) 3' and NS8 5' (TCC GCA GGT TCA CCT ACG GA) 3' (melting point $42^{\circ} \mathrm{C}$ ) for identification of fungal spp.. The PCR purified products were directly sequenced by the company Macrogen (Seoul, Korea). Blast $\mathrm{n}$-searches in GenBank permitted the identification of the level of identity with known sequences, and subsequently the spp. corresponding to the isolates. The sequences generated from 18S rRNA clustered with similar taxa. Phylogenetic analysis was done with the maximum likelihood algorithm and general time-reversible model 
of sequences evolution using the model testing feature of MEGA6 software (Tamura et al., 2011). Bootstrap consensus trees were inferred from 1000 replicates, and corresponding bootstrap values $>50 \%$ are cited in the trees.

\subsection{Rearing of Aedes aegypti}

Aedes mosquitoes were collected from public parks of Lahore, Pakistan. Aedes mosquitoes were morphologically identified according to guidelines by Rueda (2004) under the supervision of parasitology experts. The Aedes mosquito rearing was done at Laboratory of Parasitology Department, University of Veterinary Sciences, Lahore where rearing conditions were simulated. Temperature and relative humidity was set at $27^{\circ} \mathrm{C} \pm 2{ }^{\circ} \mathrm{C} \& 75 \% \pm 5 \%$ respectively. For the successful rearing of mosquitoes, temperature and humidity were maintained at the particular required levels. The humidity of the cages was maintained with the help of wet cotton draped over them. The development and various stages in the life cycle of the mosquito are affected by photoperiod and light intensity. For the uniform development of $A$. aegypti mosquitoes a cycle of 14 hours of light and 10 hours of darkness was maintained (Rund et al., 2020).

\subsection{Larvicidal bioassay}

The conidial suspension of fungal isolates was prepared. $0.01 \%$ tween 80 solution was prepared by mixing $0.1 \mathrm{ml}$ of tween 80 in $1000 \mathrm{ml}$ of distilled water in conical flask. About $20 \mathrm{ml}$ of $0.01 \%$ Tween 80 was poured in the plate containing fungal colony and swirled handily and gently to favor the detachment of conidia. The procedure was repeated for 10 15 plates of each fungal strain to obtain the suspension solution. All the prepared solutions were stirred with magnetic stirrer (IRMECO, Germany) to ensure complete mixing, and then stored at $4^{\circ} \mathrm{C}$ for further use. The number of conidia per $\mathrm{ml}$ of fungal strains was counted using haemocytometer(Marienfeld Superior, Germany) under the microscope (NIKON DS-L2, Japan) to prepare the dilutions of $10^{5}, 10^{6}, 10^{7}$ and $10^{8}$ conidia per $\mathrm{ml}$ respectively, as per requirement of experimentation. $0.01 \%$ Tween 80 was used as blank control. Conidial suspension obtained was transferred to conical flask. The larval mortality bioassays were carried out according to the standard method (WHO, 2005). Batches of 20 fourth instar larvae were exposed to a range final concentration of $10^{5}, 10^{6}, 10^{7}$ and $10^{8}$ conidia $/ \mathrm{ml}$ in polyethylene cups. All cups were covered with net sheets. 20 fourth instar larvae in water without conidial suspension served as the control group. The larval mortality was recorded after 24 h, 48 h, 72 h and 96h. Laboratory conditions were similar to rearing conditions. Three replicates of larvicidal bioassays were carried out for the study.

\section{Statistical analysis}

The larval mortality was calculated using the following formula

$$
\text { Mortality }(\%)=(\text { Dead larvae/ Total larvae }) \times 100
$$

The data on the efficacy were subjected to probit analysis (Finney, 1971; Waris et al., 2020) and LC $_{50}$ values were calculated using SPSS version 16.0.

\section{Results and Discussion}

\subsection{Identification and phylogenetic analysis of fungal isolates}

Morphological and molecular identification of the local strains confirmed the Fusarium spp. as Fusarium equiseti and Fusarium proliferatum.

\subsection{Macroscopic and microscopic identification}

Colony morphology of $F$. equiseti showed white cotton mycelium with velvety texture and peach undersurface. The Growth was rapid. Long slender macroconidia born on aerial mycelium with generally 5-7 septate and 15 to $30 \mu \mathrm{m}$ in length were present while microconidia were absent. Hyphae were septate and hyaline and chlamydospores were formed in chains (Figure 1). In case of $F$. proliferatum white villous colonies were observed with moderate to rapid growth and cottony texture. A large number of macroconidia of about $10-25 \mu \mathrm{m}$ in length with 3-5 septa and slender mycelium. A large number of slender microconidia with no septa and $5-15 \times 1.3$ to $5.5 \mu \mathrm{m}$ in size were present. Chlamydospore was absent (Figure 2).

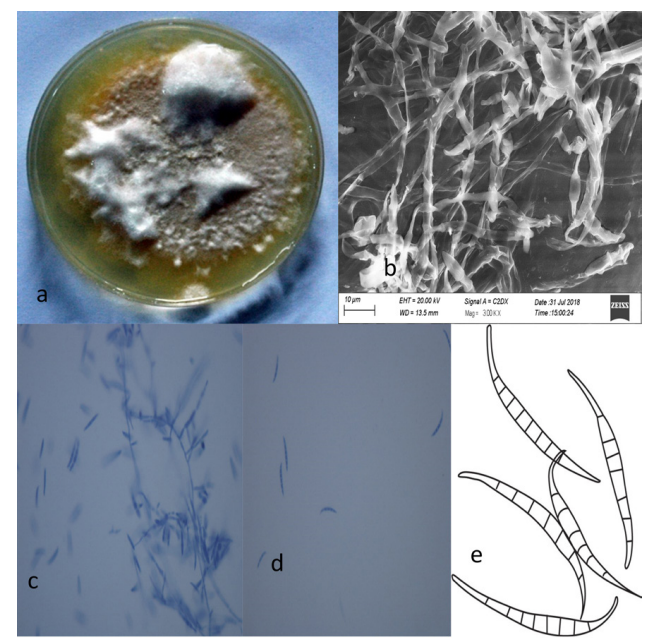

Figure 1. (a) Colony of Fusarium equiseti; (b) Image via SEM; (c) Microscopic view; (d) Macroconidia; (e)Schematic drawing of conidia.

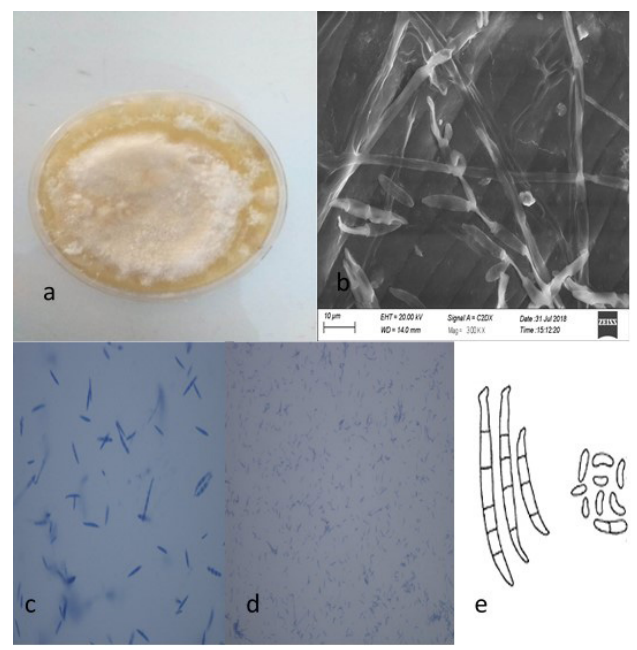

Figure 2. (a) Colony of Fusarium proliferatum; (b) Image via SEM; (c) Macroconidia; (d) Microconidia; (e) Schematic drawing of conidia. 
4.3. Molecular characterization and phylogenetic analysis of Fusarium spp.

Three sequences of ITS region of Fusarium spp. were amplified resulted in consensus sequence of up to $1700 \mathrm{bp}$. Initial BLAST (Basic Local Alignment Tool) search of the consensus of locally isolated Fusarium equiseti (MK371718) showed $99 \%$ similarity with Chinese sequence of $F$. equiset (KJ413063) with query cover of $98 \%$, while isolated strain of $F$. Proliferatum (MK371715) showed 99\% identity with F. proliferatum (LT841264.1 \& LT841250.1) of Netherlands with query cover $99 \%$. Closely related spp. were retrieved from Genbank and sequences of published work were also put in final dataset. Sequences were aligned using MUSCLE online alignment tool. Missing base pairs were corrected in BioEdit. Maximum Likelihood phylogram was constructed in MEGA 6 using Kimura 2-parameter model with Gamma distributed sites. Final dataset retrieved after phylogeny was made up to 23 sequences. Total characters of this analysis are 1088 among them 404 were conserved, 583 variable, 322 were parsimony and 260 were singleton sites. Two sequences produced during this study shows similarity with F. equiseti and F. Proliferatum (Figure 3).

\subsection{Entomopathogenic efficacy of locally isolated} Fusarium spp.

Entomopathogenic efficacy of two Fusarium spp. was evaluted against $A$. aegypti to be utilized in promoting biological control technologies. A number of researchers have concluded Fusarium spp. as efficient entomopathogen against many insects including Culex quinquefsciatus, Anopheles stephensi, Sitophilus oryzae, Tetranychus neocaledonicus, Tropidacris collaris, Lymantria obfuscate, Tetranychus urticae etc.(Munshi et al., 2008; Mohanty et al., 2008; Rachana et al., 2009; Pelizza et al., 2011; Batta, 2012; Tangtrakulwanich et al., 2014; Vivekanandhan et al., 2018; Wu et al., 2018).

Santos et al. (2020) published a review study based on a survey of peer-reviewed papers published from 2000 to 2019, presenting the significant pathogenicity of Fusarium spp. against various insects. This survey was made using search strings in a number of databases. According to the review survey at least 30 spp. and 273 isolates of Fusarium were reported as pathogenic to at least one spp. of insect. Ten complexes of Fusarium spp. harbor entomopathogenic fungi, of which F. equiseti, F. fujikuroi, F. oxysporum and F. solani spp. complexes represented the most abundant number of entomopathogenic strains.

The present study is focused on the entomopathogenic potential of locally isolated strains of Fusarium equiseti and Fusarium proliferatum from soil of forested areas of Pakistan against Aedes aegypti. Local fungal isolates offer a superior alternative to introducing a foreign biocontrol strain, as they may be better adapted to both kill local mosquitoes and survive local conditions. There are also regulatory and ecological advantages to using strains already present in the country or in the ecosystem (Bilgo et al., 2018). Results of the present study showed that both isolates were effective against $A$. aegypti population (Table 1 ). In case of $F$. equiseti the highest mortality percentage of larvae was recorded as $91 \%$ after exposure to $1 \times 10^{8}$ conidia/ml dose treatments

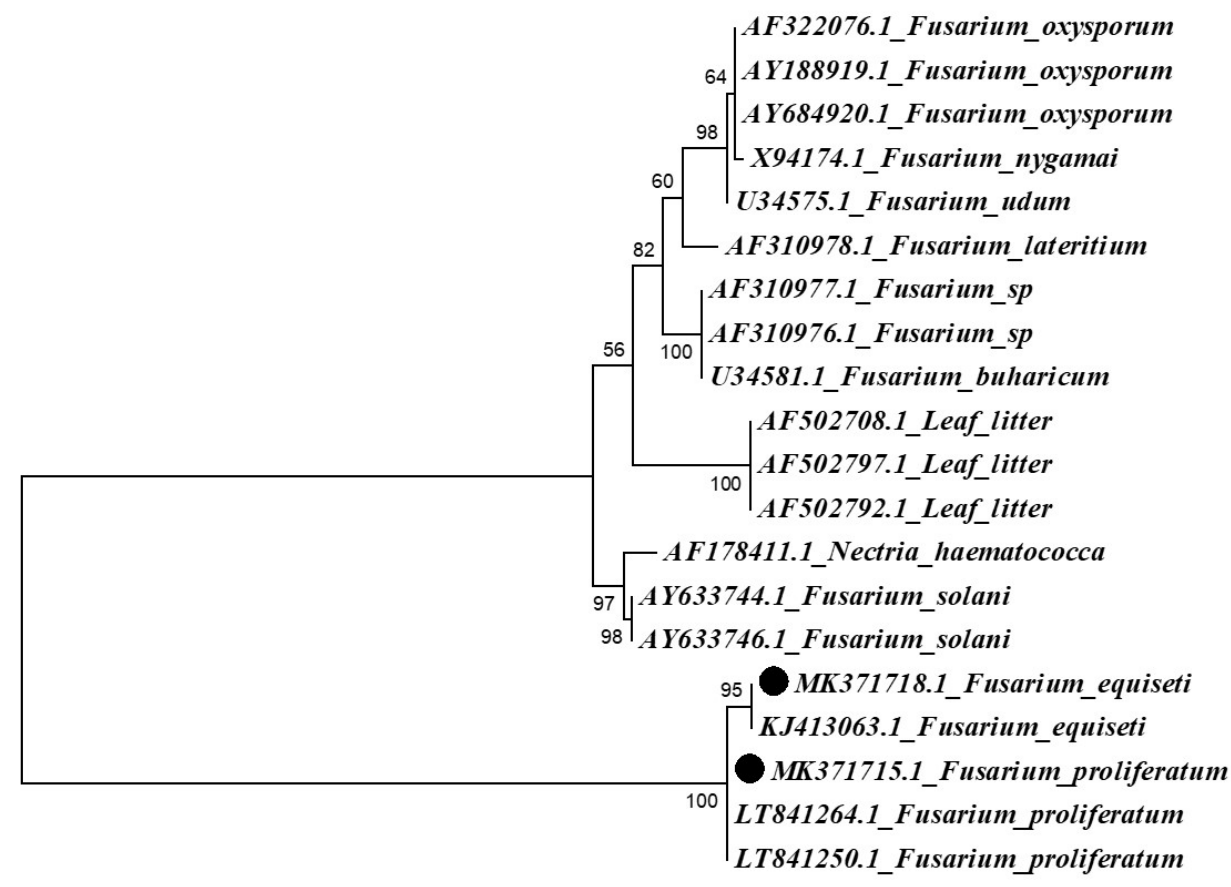

0.1

Figure 3. Phylogenetic analysis of $18 \mathrm{~S}$ region of Fusarium spp. with related species. Highlighted squences represent pakistani Fusarium species. 


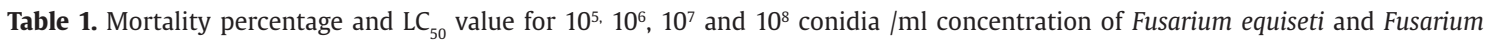
prolifertum against larvae of Aedes aegypti.

\begin{tabular}{|c|c|c|c|c|c|c|}
\hline \multirow{2}{*}{$\begin{array}{l}\text { Fungal } \\
\text { Isolate }\end{array}$} & \multicolumn{5}{|c|}{ Mean\% Mortality \pm SD } & \multirow{2}{*}{$\begin{array}{c}\mathrm{LC}_{50} \text { value (95\% confidence limit) } \\
\text { (conidia } / \mathrm{ml})\end{array}$} \\
\hline & & $\begin{array}{c}1 \times 10^{5} \\
\text { Conidia/ml }\end{array}$ & $\begin{array}{c}1 \times 10^{6} \\
\text { Conidia/ml }\end{array}$ & $\begin{array}{c}1 \times 10^{7} \\
\text { Conidia/ml }\end{array}$ & $\begin{array}{c}1 \times 10^{8} \\
\text { Conidia/ml }\end{array}$ & \\
\hline \multirow{4}{*}{$\begin{array}{l}\text { Fusarium } \\
\text { equiseti }\end{array}$} & $24 \mathrm{~h}$ & $10 \pm 0$ & $20 \pm 0$ & $40 \pm 0.42$ & $49.09 \pm 0.46$ & $3.8 \times 10^{8}\left(8.5 \times 10^{7}-1.5 \times 10^{8}\right)$ \\
\hline & $48 \mathrm{~h}$ & $25 \pm 0.46$ & $30 \pm 0.00$ & $49.09 \pm 0.46$ & $70 \pm 0.42$ & $2.0 \times 10^{6}\left(3.7 \times 10^{7}-8.6 \times 10^{7}\right)$ \\
\hline & $72 \mathrm{~h}$ & $38.33 \pm 0.52$ & $50 \pm 0$ & $70 \pm 0.42$ & $82 \pm 0.65$ & $2.9 \times 10^{7}\left(5.3 \times 10^{6}-4.8 \times 10^{7}\right)$ \\
\hline & $96 \mathrm{~h}$ & $40 \pm 0.42$ & $48.89 \pm 0.56$ & $64.44 \pm 0.65$ & $91.11 \pm 0.42$ & $7.1 \times 10^{6}\left(1.5 \times 10^{6}-2.9 \times 10^{7}\right)$ \\
\hline \multirow{4}{*}{$\begin{array}{l}\text { Fusarium } \\
\text { proliferatum }\end{array}$} & $24 \mathrm{~h}$ & $10.91 \pm 0.46$ & $18.33 \pm 0.44$ & $25 \pm 0.46$ & $38.33 \pm 0.52$ & $1.21 \times 10^{8}\left(9.4 \times 10^{7}-1.7 \times 10^{8}\right)$ \\
\hline & $48 \mathrm{~h}$ & $18.33 \pm 0.44$ & $20.91 \pm 0.46$ & $29.09 \pm 0.48$ & $46.36 \pm 0.48$ & $9.6 \times 10^{7}\left(7.3 \times 10^{7}-1.3 \times 10^{8}\right)$ \\
\hline & $72 \mathrm{~h}$ & $30.91 \pm 0.33$ & $30.91 \pm 0.33$ & $49.09 \pm 0.46$ & $76.36 \pm 054$ & $4.2 \times 10^{7}\left(2.2 \times 10^{7}-.4 \times 10^{7}\right)$ \\
\hline & $96 \mathrm{~h}$ & $38.33 \pm 0.52$ & $42 \pm 0.46$ & $52 \pm 0.58$ & $82 \pm 0.65$ & $2.6 \times 10^{7}\left(6.3 \times 10^{6}-4.7 \times 10^{7}\right)$ \\
\hline
\end{tabular}

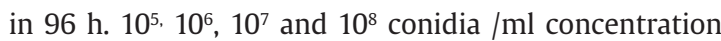
revealed positive relationship of $F$. equiseti against $A$. aegypti. $\mathrm{LC}_{50}$ values for $F$. equiseti after $24 \mathrm{~h}, 48 \mathrm{~h}, 72 \mathrm{~h}$ and $96 \mathrm{~h}$ of exposure were recorded as $3.8 \times 10^{8}, 2.9 \times 10^{7}, 2.0 \times 10^{7}$, and $7.1 \times 10^{6}$ conidia $/ \mathrm{ml}$ respectively. Entomopathogenic outcome of conidial suspensions of $F$. proliferatum against larvae of $A$. aegypti was assessed and maximum mortality was observed after exposure of $96 \mathrm{~h}(82 \%)$. $\mathrm{LC}_{50}$ values for $F$. proliferatum were $1.21 \times 10^{8}, 9.6 \times 10^{7}, 4.2 \times 10^{7}, 2.6 \times 10^{7}$ conidia $/ \mathrm{ml} 1.21 \times 10^{8}$, $9.6 \times 10^{7}, 4.2 \times 10^{7}, 2.6 \times 10^{7}$ conidia/ml respectively after $24 \mathrm{~h}$, $48 \mathrm{~h}, 72 \mathrm{~h}$ and $96 \mathrm{~h}$ of exposure. It was found that mortality percentage of larvae increased with the increase in time and conidial concentration of these entomopathogenic fungi. F. equiseti (MK371718) was found to be more effective than F. Proliferatum (MK371715) against larvae of A. aegypti. No mortality was observed in the control group. Results of present study showed that Local isolates of $F$. Equiseti and F. Proliferatum were found to be effective against larvae of Aedes aegypti. But taking long time to kill 50\% population when compare with the synthetic insecticides, is the only drawback for the use of these entomopathogenic fungi. The present research study is in agreement with the study conducted by Bilal et al. (2012) which showed the same trend. They isolated the entomopathogenic fungus Metarhizium anisopliae from the local environment, and evaluate its efficacy against the suspected dengue vector Aedes albopictus in Pakistan and the results demonstrated that $M$. anisopliae had larvicidal effect with $\mathrm{LC}_{50}$ value $1.09 \times 10^{5}$ and $\mathrm{LC}_{90}$ value $1.90 \times 10^{13}$ while it took $45.41 \mathrm{~h}$ to kill $50 \%$ of tested mosquito population.

The results of the present study indicated the potentiality of the two fungal isolates Fusarium equiseti and Fusarium proliferatum for use in control of Aedes aegypti populations in laboratory conditions. Conidial suspensions of Fusarium equiseti were found to be more effective against Aedes aegypti than Fusarium proliferatum. However, further research can be performed to determine the entomopathogenic efficacy of these fungal strains by conducting field trials.

\section{References}

ABRAR, A., MUGHAL, T.A., SARWAR, S., ONEEB, M., MALIK, K., SAIF, S. and ABBAS, M., 2020. Aspergillus pakistanicus: microscopic and phylogenetic analysis of a new entomopathogenic fungi isolated from the soil of the Changa Manga Forest, Pakistan. Applied Ecology and Environmental Research, vol. 18, no. 3, pp. 3795-3804. http://dx.doi.org/10.15666/aeer/1803_37953804.

AKHTER, A., ALI, S., KHAN, H.A.A., AMIN, H., HAIDER, M.S., AHMAD, F. and BASIT, R., 2021. Infection mechanism of Aspergillus and Fusarium species against Bemisia tabaci. Mycopath, vol. 17, no. 2, pp. 69-78.

AL-ANI, L.K.T., YONUS, M.I., MAHDII, B.A., OMER, M.A., TAHER, J.K., ALBAAYIT, S.F.A. and AL-KHOJA, S.B., 2018. First record of use Fusarium proliferatum fungi in direct treatment to control the adult of wheat flour Tribolium confusum, as well as, use the entomopathogenic fungi Beauveria bassiana. Ecology, Environmental Conservation, vol. 24, no. 3, pp. 29-34.

ANTONIO, B.F, ALMEIDA J.E.M., and CLOVIS, L., 2001. Effect of Thiamethoxam on entomopathogenic microorganisms. Neotropic Entomology, vol. 30, no. 3, pp. 437-447.

ARAUJO,J.P.M. and HUGHES, D.P., 2016. Diversity of Entomopathogenic Fungi: Which Groups Conquered the Insect Body? Advances in Genetics, vol. 94, pp. 1-39. http://dx.doi.org/10.1016/ bs.adgen.2016.01.001. PMid:27131321.

BATTA, Y.A., 2012. The first report on entomopathogenic effect of Fusarium avenaceum (Fries) Saccardo (Hypocreales, Ascomycota) against rice weevil (Sitophilus oryzae L.: Curculionidae, Coleoptera).Journal of Entomological and Acarological Research, vol. 44, no. 3, pp. e11-e11. http://dx.doi.org/10.4081/jear.2012. e11.

BILAL, H., HASSAN, S.A. and KHAN, I.A., 2012. Isolation and efficacy of entomopathogenic fungus (Metarhizium anisopliae) for the control of Aedes albopictus Skuse larvae: suspected dengue vector in Pakistan. Asian Pacific Journal of Tropical Biomedicine, vol. 2, no. 4, pp. 298-300. http://dx.doi.org/10.1016/S22211691(12)60026-4. PMid:23569917.

BILGO, E., LOVETT, B., LEGER, R.J.S., SANON, A., DABIRÉ, R.K. and DIABATÉ, A., 2018. Native entomopathogenic Metarhizium spp. 
from Burkina Faso and their virulence against the malaria vector Anopheles coluzzii and non-target insects. Parasites \& Vectors, vol. 11, no. 1, pp. 209. http://dx.doi.org/10.1186/s13071-0182796-6. PMid:29587876.

BRIMNER, T.A. and BOLAND, G.J., 2003. A review of the non-target effects of fungi used to biologically control plant diseases. Agriculture, Ecosystems \&'Environment, vol. 100, no. 1, pp. 3-16. http://dx.doi.org/10.1016/S0167-8809(03)00200-7.

CHARNLEY, A.K., and COLLINS, S.A., 2007. 10 entomopathogenic fungi and their role in pest control. Environmental and Microbial Relationships, vol. 4, pp. 159-162.

SANTOS, A.C.S., DINIZ, A.G., TIAGO, P.V. and OLIVEIRA, N.T., 2020. Entomopathogenic Fusarium species: a review of their potential for the biological control of insects, implications and prospects. Fungal Biology Reviews, vol. 34, no. 1, pp. 41-57. http://dx.doi. org/10.1016/j.fbr.2019.12.002.

DONG, Y., MORTON JUNIOR, J.C., RAMIREZ, J.L., SOUZA-NETO, J.A. and DIMOPOULOS, G., 2012. The entomopathogenic fungus Beauveria bassiana activate toll and JAK-STAT pathwaycontrolled effector genes and anti-dengue activity in Aedes aegypti. Insect Biochemistry and Molecular Biology, vol. 42, no. 2, pp. 126-132. http://dx.doi.org/10.1016/j.ibmb.2011.11.005. PMid:22198333.

DUTTA, S., 2015. Biopesticides: an ecofriendly approach for pest control. Institutions, vol. 4, no. 6, pp. 250-265.

EVANS, H.C., ELLIOT, S.L. and BARRETO, R.W., 2018. Entomopathogenic fungi and their potential for the management of Aedes aegypti (Diptera: Culicidae) in the Americas. Memorias do Instituto Oswaldo Cruz, vol. 113, no. 3, pp. 206-214. http://dx.doi. org/10.1590/0074-02760170369. PMid:29412361.

FENG, M.G., POPRAWSKI, T.J. and KHACHATOURIANS, G.G., 1994. Production, formulation and application of the entomopathogenic fungus Beauveria bassiana for insect control: current status. Biocontrol Science and Technology, vol. 4, no. 1, pp. 3-34. http://dx.doi.org/10.1080/09583159409355309.

FINNEY, D.J., 1971. Probit analysis. London: Cambridge University Press. $72 \mathrm{p}$.

HAJEK, A.E. and EILENBERG, J., 2018. Natural enemies: an introduction to biological control. London: Cambridge University Press. http://dx.doi.org/10.1017/9781107280267.

HEINISCH, M.R.S., DIAZ-QUIJANO, F.A., CHIARAVALLOTI-NETO, F., MENEZES PANCETTI, F.G., ROCHA COELHO, R., DOS SANTOS ANDRADE, P., URBINATTI, P.R., DE ALMEIDA, R.M.M.S. and LIMA-CAMARA, T.N., 2019. Seasonal and spatial distribution of Aedes aegypti and Aedes albopictus in a municipal urban park in São Paulo, SP, Brazil. Acta Tropica, vol. 189, pp. 104-113. http:// dx.doi.org/10.1016/j.actatropica.2018.09.011. PMid:30282003.

JABER, L.R. and OWNLEY, B.H., 2018. Can we use entomopathogenic fungi as endophytes for dual biological control of insect pests and plant pathogens? Biological Control, vol. 116, pp. 36-45. http://dx.doi.org/10.1016/j.biocontrol.2017.01.018.

KALAIMURUGAN, D., SIVASANKAR, P., LAVANYA, K., SHIVAKUMAR, M.S. and VENKATESAN, S., 2019. Antibacterial and larvicidal activity of Fusarium proliferatum (YNS2) whole cell biomass mediated copper nanoparticles. Journal of Cluster Science, vol. 30, no. 4, pp. 1071-1080. http://dx.doi.org/10.1007/s10876019-01568-X

LOVETT, B., BILGO, E., DIABATE, A. and ST. LEGER, R., 2019. A review of progress toward field application of transgenic mosquitocidal entomopathogenic fungi. Pest Management Science, vol.75, no. 9, pp. 2316-2324. http://dx.doi.org/10.1002/ ps.5385. PMid:30801913.
MEYLING, N. and EILENBERG, J., 2006. Occurrence and distribution of soil-borne entomopathogenic fungi within a single organic agroecosystem. Agriculture, Ecosystems E Environment, vol. 113, no. 1-4, pp. 336-341. http://dx.doi.org/10.1016/j.agee.2005.10.011.

MOHANTY, S.S., RAGHAVENDRA, K., RAI, U. and DASH, A.P., 2008. Efficacy of female Culex quinquefasciatus with entomopathogenic fungus Fusarium pallidoroseum. Parasitology Research, vol. 103, no. 1, pp. 171-174. http://dx.doi.org/10.1007/s00436-0080946-z. PMid:18327611.

MUNSHI, N.A., HUSSAIN, B., MALIK, G.N., YOUSUF, M. and FATIMA, N., 2008. Efficacy of entomopathogenic fungus Fusarium pallidoroseum (Cooke) Sacc. against gypsy moth (Lymantria obfuscata Walker). Journal of Entomology, vol. 5, no. 1, pp. 5961. http://dx.doi.org/10.3923/je.2008.59.61.

NASSAR, A.M.K., 2018. Pesticide alternatives use in Egypt: the concept and potential. In: A. NEGM and M. ABU-HASHIM, eds. Sustainability of Agricultural Environment in Egypt: Part II. The Handbook of Environmental Chemistry. USA: Springer, vol. 77, pp. 111-143. http://dx.doi.org/10.1007/698_2018_254.

NAYYAR, B.G., WOODWARD, S., MUR, L.A., AKRAM, A., ARSHAD, M., NAQVI, S.S. and AKHUND, S., 2018. Identification and pathogenicity of Fusarium species associated with sesame (Sesamum indicum L.) seeds from the Punjab, Pakistan. Physiological and Molecular Plant Pathology, vol. 102, pp. 128135. http://dx.doi.org/10.1016/j.pmpp.2018.02.001.

NIDHI, K., GAUR, N. and PANDEY, R., 2018. A survey of the local isolates of entomopathogenic fungi in Uttarakhand region. Journal of Entomology and Zoology Studies, vol. 6, no. 1, pp. 1725-1730.

PELIZZA, S.A., STENGLEIN, S.A., CABELLO, M.N., DINOLFO, M.I. and LANGE, C.E., 2011. First record of Fusarium verticillioides as an entomopathogenic fungus of grasshoppers. Journal of Insect Science, vol. 11, no. 1, pp. 70. PMid:21867437.

PELL, J.K., EILENBERG, J., HAJEK, A.E. and STEINKRAUS, D.C., 2001. Biology, ecology and pest management potential of Entomophthorales. In: T.M. BUTT, C. JACKSON and N. MAGAN, eds. Fungi as biocontrol agents: progress, problems and potential. Wallingford: CAB International, pp. 71-153.

RACHANA, R.R., MANUNATHA, M., DEVI, S.G. and NAIK, M.I., 2009. Field efficacy of entomopathogenic fungi Fusarium semitectum Berk. and Ravenel and Hisutella thompsonii Fisher against red spider mite Tetranychus neocaledonicus (Andre) on okra. Karnataka Journal of Agricultural Sciences, vol. 22, no. 1, pp. 208-209.

RUEDA, L.M., 2004. Pictorial keys for the identification of mosquitoes (Diptera: Culicidae) associated with dengue virus transmission. Washington: Department Of Entomology, Walter Reed Army Institute of Research.

RUND, S.S., LABB, L.F., BENEFIEL, O.M. and DUFFIELD, G.E., 2020. Artificial Light at Night Increases Aedes aegypti Mosquito Biting Behavior with Implications for Arboviral Disease Transmission. The American Journal of Tropical Medicine and Hygiene, vol. 103, no. 6, pp. 2450-2452. http://dx.doi.org/10.4269/ajtmh.20-0885. PMid:33069264.

SHAH, P.A. and PELL, J.K., 2003. Entomopathogenic fungi as biological control agents. Applied Microbiology and Biotechnology, vol. 61, no. 5-6, pp. 413-423. http://dx.doi.org/10.1007/s00253-0031240-8. PMid:12764556.

SHANG, Y., FENG, P. and WANG, C., 2015. Fungi that infect insects: altering host behavior and beyond. PLoS Pathogens, vol. 11, no. 8, pp. e1005037. http://dx.doi.org/10.1371/journal.ppat.1005037. PMid:26248013. 
SUMMERELL, B.A., SALLEH, B. and LESLIE, J.F., 2003. A utilitarian approach to Fusarium identification. Plant Disease, vol. 87, no. 2, pp. 117-128. http://dx.doi.org/10.1094/PDIS.2003.87.2.117. PMid:30812915.

TAMURA, K., PETERSON, D., PETERSON, N., STECHER, G., NEI, M. and KUMAR, S., 2011. MEGA5: molecular evolutionary genetics analysis using maximum likelihood, evolutionary distance, and maximum parsimony methods. Molecular Biology and Evolution, vol. 28, no. 10, pp. 2731-2739. http://dx.doi.org/10.1093/molbev/ msr121. PMid:21546353.

TANGTRAKULWANICH, K., REDDY, G.V., WU, S., MILLER, J.H., OPHUS, V.L. and PREWETT, J., 2014. Efficacy of entomopathogenic fungi and nematodes, and low risk insecticides against wheat stem sawfly, Cephus cinctus (Hymenoptera: cephidae). The Journal of Agricultural Science, vol. 6, no. 5, pp. 1-9.

TEETOR-BARSCH, G.H. and ROBERTS, D.W., 1983. Entomogenous Fusarium species. Mycopathologia, vol. 84, no. 1, pp. 3-16. http:// dx.doi.org/10.1007/BF00436991. PMid:6369143.

VASANTHA-SRINIVASAN, P., KARTHI, S., CHELLAPPANDIAN, M., PONSANKAR, A., THANIGAIVEL, A., SENTHIL-NATHAN, S., CHANDRAMOHAN, D. and GANESAN, R., 2019. Aspergillus flavus (Link) toxins reduces the fitness of dengue vector Aedes aegypti (Linn.) and their non-target toxicity against aquatic predator.
Microbial Pathogenesis, vol. 128, pp. 281-287. http://dx.doi. org/10.1016/j.micpath.2019.01.014. PMid:30633984.

VIVEKANANDHAN, P., KARTHI, S., SHIVAKUMAR, M.S. and BENELLI, G., 2018. Synergistic effect of entomopathogenic fungus Fusarium oxysporum extract in combination with temephos against three major mosquito vectors. Pathogens and Global Health, vol. 112, no. 1, pp. 37-46. http://dx.doi.org/10.1080/20477724.2018.143 8228. PMid:29457957.

WARIS, M., NASIR, S., ABBAS, S., AZEEM, M., AHMAD, B., KHAN, N.A., HUSSAIN, B., AL-GHANIM, K.A., AL-MISNED, F., MULAHIM, N. and MAHBOOB, S., 2020. Evaluation of larvicidal efficacy of Ricinus communis (Castor) and synthesized green silver nanoparticles against Aedes aegypti L. Saudi Journal of Biological Sciences, vol. 27, no. 9, pp. 2403-2409. http://dx.doi.org/10.1016/j. sjbs.2020.04.025. PMid:32884423.

WORLD HEALTH ORGANIZATION - WHO, 2005. Guidelines for laboratory and field testing of mosquito larvicides (No. WHO/ CDS/WHOPES/GCDPP/2005.13). Geneva: WHO.

WU, S.Y., EL-BORAI, F.E., GRAHAM, J.H. and DUNCAN, L.W., 2018. The saprophytic fungus Fusarium solani increases the insecticidal efficacy of the entomopathogenic nematode Steinernema diaprepesi. Journal of Invertebrate Pathology, vol. 159, pp. 87-94. http://dx.doi.org/10.1016/j.jip.2018.10.004. PMid:30300629. 